Review Article / Derleme

\title{
"Tactics" of the Food Industry and Preventive Approach in Public Health Perspective
}

\section{Halk Sağlığı Bakış Açısıyla Gıda Endüstrisi “Taktikleri” ve Önleme Yaklaşımları}

Zeynep Devran ${ }^{*}$, Dilek Aslan ${ }^{1}$

\begin{abstract}
The aim of this article is to discuss what the prominent tactics of the food industry which could have influenced "health" and "wellbeing" negatively and how to address the preventive strategies in this regard in public health approach. Food industry is resorting to a variety of "tactics" to increase its activities on the market. The similarity of the combination of food and beverage and tobacco industry and the "tactics" they use is remarkable. The ethical violations used within these "tactics" may have the risk to affect certain groups including children and young people. Industrial tactics in the scientific literature include introduction of harmful products, misleading marketing campaigns, targeting of children and other vulnerable groups, corporate lobbying, material contributions, and negative approaches to informatics/scientists.Prevention or elimination of the activities of the food industry which could have a negative impact on the individual/community health is crucial. Based on public regulations, all responsible components should act in accordance with the precautionary principle of public health.
\end{abstract}

Key words: Food, industry, ethics

\section{ÖZET}

$\mathrm{Bu}$ yazının amacı gıda endüstrisindeki "sağlık" ve "iyilik" halini olumsuz etkileyebilecek öne çıkan taktiklerin neler olabileceğini tartışmak ve bu olumsuz etkilere yönelik olarak alınabilecek önlemleri halk sağlığı yaklaşımı ile ele almaktır. Gıda endüstrisi, piyasadaki etkinliklerini arttırmak için çeşitli "taktiklere" başvurmaktadır. Yiyecek, içecek ve tütün endüstrisinin birlikteliği ve kullandıkları "taktiklerin/oyunların" benzerliği dikkat çekmektedir. Kullanılan bu "taktikler" de etik ihlaller çocukların ve gençlerin içinde olduğu bazı özel grupları etkilemektedir. Bilimsel literatürde yer alan endüstri taktikleri arasında; zararlı ürünlerin tanıtımı, yanıltıcı pazarlama kampanyaları, çocukların ve diğer hassas grupların hedef alınması, şirket lobiciliği, maddi katkılar ve bilime/bilim insanlarına yönelik olumsuz yaklaşımlar yer almaktadır. Gıda endüstrisinin sağlığı olumsuz yönde etkileyecek faaliyetlerinin önlenmesi ya da ortadan kaldırılması birey ve toplum için son derece önemlidir. Kamusal düzenlemeler zemininde sorumluluğu olan tüm bileşenler, halk sağlığında ihtiyatlılık ilkesi gereğince hareket etmelidirler.

Anahtar kelimeler: Gıda, endüstri, etik

Received Date / Geliş Tarihi: 13.03.2018, Accepted Date / Kabul tarihi: 24.05.2018

${ }^{1}$ Hacettepe Üniversitesi Tıp Fakültesi Halk Sağlığı Anabilim Dalı

*Address for Correspondence / Yazışma Adresi: Zeynep Devran, Hacettepe Üniversitesi Tıp Fakültesi Halk Sağlığı Anabilim Dalı, Ankara-TÜRKIYYE E-mail: zynpdvrn@gmail.com

Devran Z, Aslan D. Halk Sağlı̆̆ı Bakış Açısıyla Gıda Endüstrisi “Taktikleri/Oyunları” ve Önleme Yaklaşımları. TJFMPC, 2018;12(4):

DOI: $10.21763 /$ tjfmpc.465769 


\section{GíRiş}

Beslenme: büyüme, gelişme, organların fonksiyonel çalışması, yaşamın devamı, sağlığın korunması ve üretken olarak yaşama için gıdalardan yararlanmadır. Beslenmede amaç: açlığı gidermek, zevk duymak ve sağlıklı, yani yeterli ve dengeli beslenebilmektir. ${ }^{1}$ Sağlıklı beslenme ise tüm besin ögelerinin yaş, cinsiyet, fiziksel aktivite düzeyi ve süresi gibi değişen özelliklere göre yeterli ve dengeli olarak alınmasıyla, ideal vücut ağırlığının devamlılığının sağlanmasıdır. ${ }^{1,2,3}$

Roma'da 1992 yılında Gıda ve Tarım Örgütü (FAO) tarafindan düzenlenen Uluslararası Gida Konferansı'nda yeterli ve dengeli beslenmenin bir hak olduğu vurgusu yapılmıştır. Konferansta gıda güvenliği konusuna da değinilmiştir. Gıda güvenliği, tüketim için var olan gıdaların "tarladan/çataldan sofraya" gelinceye kadar olan tüm süreçlerini kapsamaktadır ve gıdalarda olabilecek her türlü fiziksel, kimyasal ve biyolojik zararların bertaraf edilmesi olarak tanımlanmaktadır. ${ }^{4}$

Sağlıksız ortamda elde edilen bir üründen sağlıklı gıda oluşturmak mümkün olmadığından gerek bitkisel gerek hayvansal gıdaların kalitesi, güvenli gıda elde edilmesinde son derece önemlidir. Endüstriyel aşamada kullanılan teknoloji, uygulanan yöntemler, gıdaların kalitesini ve dolayısıyla gıda güvenliğini doğrudan etkilemektedir. Endüstriyel aşamadaki bütün süreçlerin denetimlerinin en uygun koşullarda yapılması gerekir. ${ }^{5}$

Bu yazının başlıca amacı gıda endüstrisinin sağlığı olumsuz etkileme riski olan bazı taktiklerinin neler olabileceğini ve alınabilecek önlemleri halk sağlığı bakış açısıyla tartışmaktır.

\section{Sağlıklı beslenme açısından risk oluşturabilecek konular}

Sağlıklı beslenme açısından risk oluşturabilecek temelde üç sorun vardır. Birincisi, gereğinden fazla yemek yiyerek enerji ve besin ögelerinin vücuda haddinden fazla alınmasıdır. Gerektiğinden fazla alınan enerji, dokularda yağ olarak birikmekte ve şişmanlık (obezite) sorunu ortaya çıabilmektedir. $\mathrm{Bu}$ durum hipertansiyon, diyabet ve kalp-damar hastalıkları gibi kronik hastalıkların oluşmasına neden olmaktadır.
İkincisi, yeterli beslenmeye rağmen uygunsuz besin alımı ve/ veya yanlış pişirme yöntemi nedeniyle besin ögelerinden gerektiği düzeyde faydalanamamadır. Üçüncü sorun ise besin ögelerinin yetersiz alınmasıdır. Besin ögeleri, yetersiz alındığında organların işlevinin bozulmasıyla çeşitli sağlık sorunlarının ortaya çıkmasıdır. ${ }^{3}$

Birincil (primer) beslenme hastalıklarına bağl1 olarak; protein-enerji yetersizlikleri oluşur (Marasmus, Marasmik Kwashiorkor, Kwashiorkor), vitamin ve mineral eksiklikleri oluşarak çeşitli hastalıklar meydana gelir (C avitaminozu gelişerek Skorbüt hastalığının oluşması, demir eksikliği anemisi gibi mineral eksikliğine bağlı hastalıkların oluşması gibi) ve aşırı beslenmeye bağlı hiper vitaminozlar ve şişmanlık meydana gelir. İkincil (sekonder) beslenme hastalıklarına bağlı olarak ise diabetes mellitus (DM), gut gibi metabolizma bozukluğu hastalıkları, hipertansiyon, ateroskleroz, karaciğer hastalıkları gibi dejeneratif hastalıklar ve benign ve malign kanserler meydana gelir. ${ }^{1}$

Yetersiz ve dengesiz beslenmeden etkilenen gruplar daha çok bebek ve çocuklar, gençler, doğurganlık çağındaki kadınlar, gebe ve emziren kadınlar, yaşlılar ve çalışanlardır. ${ }^{3}$ Büyüme ve gelişme geriliği özellikle bebek, çocuk ve gençler için önemlidir. Gebe ve emziren kadınlar ve yaşlılar gibi risk grupları için hastalıklara direncin azalması yine beslenmeye bağlı olarak oluşabilecek ciddi problemlerdendir ve beslenme sorunlarına bağlı olarak hastalıkların şiddet ve sıklığının arttığı görülmektedir. ${ }^{1}$

Sağlıklı insan üretken insandır. Çalışan bireyler, sağliklı bir şekilde çalışmak ve üretken olmak için temel hak olan sağlıklı beslenmeye ihtiyaç duyarlar. Toplumsal düzen içinde bağımsız bireylerin artması, sağlıklı çalışanların artmasıyla ve böylece ekonomik sorunların azalmasıyla sonuçlanacaktır. ${ }^{1,3}$

"Küresel Hastalık Yükü Çalışması 2010" içeriğine göre DSÖ Avrupa bölgesindeki her üye devlette sağllk ve refahı sekteye uğratan en önemli faktörlerin başında beslenme faktörleri gelmektedir. Yetersiz beslenme, mikro besin ögesi eksiklikleri, fazla kiloluluk ve șișmanlığın yanında sağlıksız beslenmeden kaynaklanan bulaşıcı olmayan hastalıklar $(\mathrm{BOH})$ dâhil olmak üzere sağlıksız beslenmenin bireyler, aileler, toplumlar ve devletler için yüksek sosyal ve ekonomik maliyetleri beraberinde getirdiği 
bilinmektedir. $^{6} \quad$ Amerika Birleşik Devletleri'nde (ABD) her yıl yaklaşık 48 milyon insan, gida kaynaklı hastalıklara yakalanmaktadır. ${ }^{7}$ Sağlıksız diyet nedeniyle ise ABD'de günde yaklaşık 1000 kardiyovasküler ve diyabet kaynaklı ölüm olmaktadır. Diyetle ilgili kronik hastalıkların doğrudan ve dolaylı maliyetleri şaşırtıcıdır ve ABD'de yılda bir trilyon dolara kadar çıkacağı tahmin edilmektedir. $^{8}$

Sakatlanma ve ölümün başlica sebebi olan BOH'lardan en ciddi seviyede etkilenen DSÖ bölgesi, Avrupa bölgesidir. Kardiyovasküler hastalıklar, diyabet, kanser ve solunum hastalıkları (dört büyük BOH) birlikte hastalık yükünün $\% 77$ 'sine ve vaktinden önce ölümlerin neredeyse \%86'sına neden olmaktadır. Fazla kilo (Beden Kütle İndeksi $>25 \mathrm{~kg} / \mathrm{m}^{2}$ ), aşırı enerji, doymuş yağ, trans yağ, şeker ve tuz tüketimin yanında yetersiz meyve, sebze ve tam tahıl tüketimi başlıca risk faktörlerindendir. Bazı ülkelerde aynı anda hem aşırı kilo ve şişmanlığın hem de beslenme eksikliğinin endişe verici düzeylerde olduğu görülmektedir. Son birkaç on yıl içerisinde Avrupa bölgesindeki birçok ülke aşırı kilo ve şişmanlığın arttığını rapor etmişlerdir. ${ }^{6}$ Gün geçtikçe farklı beslenme alışkanlıkları ve fiziksel aktivite yetersizliği gibi birtakım olumsuz koşulların bir araya gelmesiyle şişmanlık daha da artmaktadır. ${ }^{9}$

Çocukluk yaş grubunda da şişmanlık giderek daha ciddi bir halk sağllğ 1 sorunu haline gelmektedir. Dünyada 0-4 yaş grubu çocuklarda, fazla kilolu ve şişman çocuk sayısı 1990'da 32 milyon iken 2016 yılında 41 milyona ulaşmıştır. Fazla kilolu ve şişman çocukların büyük çoğunluğu, gelişmekte olan ülkelerde yaşamaktadır. İki bin yirmi beş y1lında tüm dünyadaki fazla kilolu ve şişman çocuk sayısının 70 milyona ulaşacağı tahmin edilmektedir. Çocukluk çağında var olan şişmanlığın da başta diyabet ve kalp hastalığı olmak üzere çok sayıda ciddi sağlık sorununa neden olduğu bilinmektedir. ${ }^{9}$

\section{Gıda endüstrisi ve ilgili genel durum analizi}

"Gıda endüstrisi", için resmi bir tanım bulunmamakla birlikte, gida üretimi ve satışının tüm yönlerini kapsamaktadır. Genel anlamda gıda endüstrisinin alt başlıkları: tarım ve hayvancılık, çiftlik ekipmanı ve ziraat kimyasalı üretimi, gıda işleme, ambalajlama ve etiketleme, depolama, dağıtım, düzenleyici çerçeveler, finansman, pazarlama, perakende satış, yiyecek içecek sağlama, araştırma ve geliştirme, eğitim olarak sıralanabilir. ABD Tarım Bakanlığı Ekonomik Araştırma Servisi (USDA), tüm bu işletmeyi tanımlamak için “Gıda Sistemi (Food System)"terimini kullanmaktadır. ${ }^{10}$

\subsection{Gıda endüstrisi}

Tüketici Ürünlerinin Küresel Güçleri 2015 yılı raporuna göre dünya genelinde var olan ilk on endüstri firmasının dördü yiyecek içecek ve tütün üzerine çalışmaktadır. Ayrıca gıda endüstri firmalarının tütün endüstrisi ile olan yakınlığı da görülebilmektedir. ${ }^{11}$ Gıda alanında dünyada bazı şirketler öne çıkmaktadır. En büyük 10 paketlenmiş gıda ürünleri firmasının piyasa payı \%3-15 arasında değişmektedir. Dünyada en büyük 10 alkolsüz içecek firmasının piyasa payı 2009 yılında \%52 iken sadece iki firmanın toplam payı \%37'dir. Ülkemizde de bu firmalar toplam içinde \%40 paya sahiptirler. $^{12}$

Avrupa Birliği, dünya genelinde yiyecek ve içecek sektöründe önemli bir role sahiptir. Çin ve Brezilya'nın önceki yıllarda artan payları nedeniyle (2007 yılı itibarıyla payları sırasıyla $\% 6,5$ ve $\% 7,4)$, AB'nin küresel ihracat pazarındaki payı 1998'deki \%24,6 seviyesinden 2007 'de \%19,8'e düşmüştür. ${ }^{13}$

Türkiye'de yiyecek içecek sektöründeki önemli alt pazarlar; et ve et ürünleri, unlu mamuller, süt ürünleri, sebze ve meyveler, yağlar, şekerli ve çikolatalı ürünler, alkollü ve alkolsüz içecekler, hazır tüketilen gıdalar ve bebek mamalarıdır. Türk halkının beslenme şeklinde unlu mamullerin yeri oldukça önemli olduğundan toplam gıda firmalarının çoğu (\%65) un ve unlu mamuller alt sektöründe bulunmaktadır. Ülkemizde imalat sanayisinde 2011 y1lsonu itibariyle 4.729 adet uluslararası sermayeli şirket faaliyet göstermektedir. $\mathrm{Bu}$ rakam, toplam uluslararası sermayeli şirketlerin \%16'sını oluşturmaktadır. İmalat sanayi içerisinde kimya sektörü 523, gıda ürünleri, içecek ve tütün sektörü 504 ve tekstil sektörü 468 adet uluslararası sermayeli şirket ile ilk üç sırayı paylaşan alt sektörler olmuşlardır. ${ }^{14}$

\section{Gıda endüstrisinin beslenme üzerindeki olası etkileri}

Güvenli gıda kaynakları ulusal ekonomilere, gida ve beslenme güvenliğine katkıda bulunmakta ve sürdürülebilir kalkınmayı desteklemektedir. Kentleşme ve seyahat dahil olmak üzere yaşam tarzındaki değişikliklerle halka açık yerlerde yemek yeme ve hazır 
gıdaları satın alma eğilimi artırılmaktadır. Günümüzde teknolojik gelişmeler ile var olan yenilikler, insanların hizmetine sunulmakta ve küreselleşmenin etkisiyle daha geniş bir yelpazede gıdalara yönelik artan tüketici talebi tetiklenmektedir. ${ }^{14}$

Dünya nüfusunun artmasıyla çoğalan gida talebini karşılamak için tarımın ve hayvancılığın arttırılması ve sanayileşmesi g1da güvenliği için hem firsatlar yaratmakta hem de zorluklar çıkarmaktadır. Bu zorluklar, gıda güvenliğini sağlamak için gıda üreticilerine ve gida işleyenlere daha fazla sorumluluk yüklemektedir. ${ }^{15}$

Uluslararası Gıda ve Tarım Örgütü (FAO) gıda güvenliğini sağlamak için gıdaya erişimde eşitlik, gıda maddelerine ulaşım, sürdürülebilir üretimin sağlanması ve gıda kalitesi gibi bazı koşulları tanımlamıştır. ${ }^{15}$

Gıdaya erişimde eşitlik, herkesin dengeli ve kaliteli beslenme için güvenli gıdanın temin edilmesinde eşit haklara sahip olmasıdır. Sürdürülebilir üretimin sağlanması, özellikle tarım açısından doğal kaynakların doğru kullanımı, çevreye ve doğaya saygılı, aynı zamanda ekonomik olarak sürdürülebilir tarım vasıtasıyla artan nüfusun ihtiyaçlarının yeterli ve kaliteli bir şekilde karşılanmasını ifade etmektedir. Gıdaya erişim (ulaşım): gıdanın satın alınması, pazarlanması, gerektiğinde yeterli gıdaya erişim konusunda sorun yaşayan üçüncü dünya ülkelerine düzenli gıda yardımlarıyla ve alınacak tedbirlerle besin ihtiyaçlarının karşılanmasını ifade etmektedir. Gıda kalitesi (niteliği) ise sadece niceliksel olarak yeterli gıdanın temini değil aynı zamanda niteliksel olarak da gereken kalite şartlarının yerine getirilmesi ve insan sağlığ açısından risk oluşturmamasını tanımlamaktadır. ${ }^{16}$

Besin maddelerinin güvensiz olduğu yerlerde, insanlar daha az sağlıklı diyetlere kayma eğilimi göstermekte ve kimyasal, mikrobiyolojik ve diğer tehlikelerin sağlık riskleri oluşturduğu daha "güvensiz gidalar" tüketmektedirler. ${ }^{16}$ Örneğin, genetiği değiştirilmiş ürünlerin ve gida maddelerinin g1da zinciri üzerindeki etkisinin gittikçe arttığ1 yönünde endişeler vardır. ${ }^{16}$

Son 50 yılda tarımsal alanda yapılan uygulama değişiklikleri, üretkenlik artışı, gıdaların çeşitliliği ve mevsimsel bağımlılığın azalması yoluyla endüstri, insanlara gida sağlama kapasitesini arttırmıştır. Artan gelir seviyeleri ve düşen gıda fiyatlarının bir sonucu olarak gida alımı da artmıştır. ${ }^{17}$

Modern gida endüstrisinin her zamankinden daha yüksek getiri sağlaması ve daha yüksek miktarda üretim yapmasıyla ilgili durum, çeşitli çevresel ve halk sağlığı sorunlarını ve endişelerini ortaya çıkarmıştır. Örneğin, küresel gida üretim zincirinin hizla sanayileşmesinin çevresel etkileri, önemli tarımsal üretim alanlarının ve balık stoklarının tükenmesi, toprak erozyonu ve ormansızlaşma gibi önemli sorunlara neden olmuştur. Pestisit kalıntıları, antibiyotikler ve veteriner ilaçları, gıda patojenleri, kurşun ve cıva vb. çevresel toksinler gibi organik kirleticilerin halk sağlı̆̆ üzerindeki etkileri konusunda halkın endişesi artmaktadır. ${ }^{17}$

Ulusötesi gıda şirketleri (imtiyaz sahipleri ve imalatçılar), ayaküstü beslenme (fast food) pazarı, işlenmiş gıdalar ve Batı yaşam tarzının itici gücünü, gelişmekte olan ülkelerde gittikçe yaygınlaştırmıştır. Gelişmekte olan ülkelerden modern işlenmiş gıdaların tüketiminin artmasının yanı sıra gelişmekte olan ülkeler geleneksel yemeklerin işlenmiş hallerini de üretmektedir. Sonuç olarak gida sistemlerinin küreselleşmesiyle gelişmekte olan ülkelerdeki geleneksel yiyecekler, gelişmiş ülkelerdeki ayaküstü beslenme ürünleri giderek daha bol ve ucuz gida teknolojisiyle dönüştürülmektedir. Bununla birlikte çok sıklıkla yalnızca meşrubat, ayaküstü beslenme ve diğer ulusötesi şirketler de dahil olmak üzere modern gida işleme, pazarlama ve dağıtım sektörlerinin küreselleşmesine atıfta bulunmaktadır. ${ }^{17}$

Kentleşme; yeni ve geliştirilmiş pazarlamaya, dağıtım altyapısına ve ulusötesi şirketlerin hâkim olduğu büyük süpermarketleri çekmeye, daha ulaşılabilir koşullara ve bunun sonucu olarak ithalatın artmasına sebep olmuştur. Bu faktörler, gıda tüketim kalıplarının küreselleşmesini ve insan sağlığının etkilenmesini hızlandırmaktadır. ${ }^{17}$

Sektörde etkin mağazalar orta gelirli ülkelerde de önemli yatırımlar yapmaktadır. Çok uluslu gıda şirketlerinin doğrudan yabancı yatırım yaptıktan sonra gelişmekte olan ülkelerde işlenmiş gıdaların varlığı da artmıştır. Böylece ticaret politikalarında yapılan değişiklikler, işlenmiş gıdaların varlığının ve alımının artmasına yardımcı olmuştur. Sonuç olarak ticaret politikaları, artan oranlarda şişmanlık, kardiyovasküler hastalık ve kanser gibi kronik hastalıklarla ilişkili olan "beslenme geçişine" katkıda 
bulunarak sağlık üzerinde etkilere sahip olmuştur. Örneğin Hindistan, Pakistan ve Sri Lanka gibi ülkelerde yetişkin başlangıçlı diyabet ve kardiyovasküler hastalıklar epidemi düzeyindedir. 2025 y1lına kadar diyabetik hastaların beşte birinin Hintli, dörtte üçünün gelişmekte olan ülkelerde bulunacağı tahmin edilmektedir. Sonuç olarak gıdaların yüksek miktarda alınması, özellikle enerjisi yoğun gıdalar, şişmanlık ve diğer bulaşıcı olmayan hastalıkların kişi ve toplum içinde görülme sıklığını arttıracaktır. Hindistan ve Çin'de şişmanlık ve diyabetin ekonomik etkisini araştıran yeni bir araştırma, maliyetlerin hızla artarak GSMH'nin önemli bir bileșenini oluşturduğunu tespit etmiştir. ${ }^{17}$

Kırsal alanlarda yapılan işlere ve boş zamanlardaki hareketsizliğe kıyasla daha yüksek bir enerji alımı ve kentsel işlerde daha az enerji harcamaları, gelişmekte olan ülkelerdeki şişmanlık ve diyabetin kentlerde kırsal alanlardan daha hızlı ilerlediği anlamına gelmektedir. ${ }^{17}$

Hastalık yükü çalışmaları sonuçlarına göre bulaşıcı hastalıkların yükünde azalma, bulaşıcı olmayan hastalıkların yükünde ise artış vardır. Halen dünyada devam eden kentleşme, sanayileşme, tütün tüketimi başta olmak üzere sağlıklı olmayan beslenme süreçleri, besin üretimi ve saklanmasındaki yöntemler gibi çok sayıda neden sayılabilir. ${ }^{18}$

Bugün tüm dünyada ölümlerin üçte ikisinin (\%63) nedeni bulaşıcı olmayan hastalıklardır. Erken ölümlerin dörtte üçünün nedeni; kardiyovasküler hastalık, kanser, diyabet ve kronik solunum yolu hastalığıdır. Adı geçen hastalıklar sadece gelişmiş ülkeler için değil, günümüzde gelişmekte olan ülkeler için de önemli sorunlar arasındadır. ${ }^{19}$

Hastalık yükü açısından ülkemizde, geçmiş y1llarda öncelikli sorun anne-çocuk sağlığı sorunları iken şimdi bulaşıcı olmayan hastalıklara doğru bir yer değiştirme söz konusudur. Ulusal Hastalık Yükü çalışması 2013 yılı verilerine göre; ülkemizde 2000 yılında \%68 olan bulaşıcı olmayan hastalıkların yükü \%81'e yükselmiştir. Dünya Sağlık Örgütü bulaşıcı olmayan hastalıkların 2020'de küresel hastalık yükünün \%80'ini oluşturacağını, gelişmekte olan ülkelerdeki her 10 ölümün yedisinden sorumlu olacağını (bunların yarısı 70 yaş altı ölüm) belirtmektedir. Bulaşıcı olmayan hastalıkların oluşmasında: sigara ve alkol kullanımı, sedanter yaşam, aşırı kiloluluk ve sağlıksız beslenme gibi yaşam tarzına ilişkin, büyük ölçüde “önlenebilir ortak risk faktörleri” olduğu görülmektedir. ${ }^{20}$

\section{Gıda endüstrisi"'taktikleri",}

Gıdalardaki hilelerin tarihi esasen Orta Çağ’a kadar dayanmaktadır. Günümüzde durum çok daha karmaşıktır. Bilimsel ve teknolojik gelişmeler gıda ürünlerindeki hilelerin tespitini kolaylaştırırken, aynı bilimsel ve teknolojik gelişmeler daha karmaşık hilelerin de ortaya çıkmasına yardımcı olmaktadır ve teknolojik gelişmelerin etkisiyle ürünlerindeki hilelerin tespiti de daha zor bir hal almaktadır. Bilinçsizce kullanılan katkı maddeleri, kontamine gıdaların (pestisitler, ağır metaller, hormonlar ve diğer bulaşanlarla) tüketime sunulması insan sağlığını tehdit eden en önemli gıda hilelerindendir. ${ }^{16}$

Uluslararası Gıda ve Tarım Örgütü (FAO) ticari etik ilkelerine göre; gidalar, toksik, tehlikeli ve sağlığa uygun olmayan maddeler içermemeli; gıda etiketinde yanlış, yanıltıcı ve eksik bilgiler bulunmamalı; hazırlama, taşıma, depolama ve ambalajlama gibi işlemler sağlıksız koşullarda yapılmamalıdır. Gıda etiğine göre gidanın hazırlanma sürecinden sunumuna kadar tüketicinin, gıdanın hiçbir zararlı etkisine maruz kalmaması gerekmektedir. ${ }^{20}$

Gıda endüstrisinin taktiklerinin bazıları diğer endüstrilerin taktikleri ile benzerlik göstermektedir. $\mathrm{Bu}$ konuda tütün endüstrisi taktikleri ile benzerlikler dikkat çekmektedir. $\mathrm{Bu}$ benzerliğin altında yatan farklı dinamikler olmakla birlikte gida endüstrisinin diğer sektörler ve ürünleriyle önemli heterojenik ilişkilerinin varlığı bilinmektedir. ${ }^{8}$ Tütün, alkol ve abur cubur yiyecekler sağlıksız emtia (mal) endüstrisi kapsamında olup toplumun sağlığına potansiyel olarak zararlı ürünler ya da hizmetler üretenler arasında gösterilmektedir. ${ }^{17}$

Tüketimin artmasıyla ortaya çıkan sonuçları tanımlayan ve keşfeden ilk ekonomistlerden biri olan John Kenneth Galbraith (1908-2006), gıda, tütün, ilaç, otomobil ve alkol endüstrisine hakim olan büyük firmaların satışları artırmak için farklı pazarlama taktikleri kullandıklarını vurgulamıştır. ${ }^{17}$

Dünya Sağlık Örgütü hem kendi rolünün bir parçası olarak hem de daha geniş kapsamda tütün ve benzeri konularda savunuculuk eyleminin önemine dikkat çekmiştir. "Tütün endüstrisinin uygulamalarını anlamanın tütün 
kontrol politikalarının başarısı için hayati önem taşıdığını" vurgulamıştır. ${ }^{21}$

Ulusal Diş Çürüğü Programı (NCP) gibi Sigara İçme ve Sağlık Programı, zarar azaltma

Aşağıda yazılı kimi diğer taktikler ${ }^{23}$ de gıda ve tütün endüstrisi arasındaki benzeşmeler için örnek olarak kabul edilebilir:

$\checkmark$ Ürünün sağl1k üzerine olumsuz etkilerini inkâr etmek

$\checkmark$ Tüketicileri aldatmak

$\checkmark$ Endüstri karşıtlarının etkisini/ saygınlığını azaltmak

$\checkmark$ Özel gruplara yönelmek, yeni pazarlar geliştirmek

$\checkmark \quad$ Reklam stratejileri kullanmak stratejilerine odaklanmış ve birincil amacı olan güvenli bir sigara geliştirmek bir örnek olarak değerlendirilebilir. ${ }^{22}$

$\checkmark$ Yasal düzenlemeye yönelik girişimlerin karşısında durmak, yasal düzenlemeleri erteletmek

$\checkmark$ Yasal düzenlemelere zarar veren çalışmalar içinde olmak

$\checkmark$ Endüstriye karşı açılan davaların savunuculuğunu yapmak

$\checkmark$ "Özdenetleme" söylemi üzerinden çeşitli "aldatmacalar" içinde olmak

Tütün endüstrisi tarafindan kullanılan taktiklerin ilişkileri Şekil 1'de açıklamıştır.

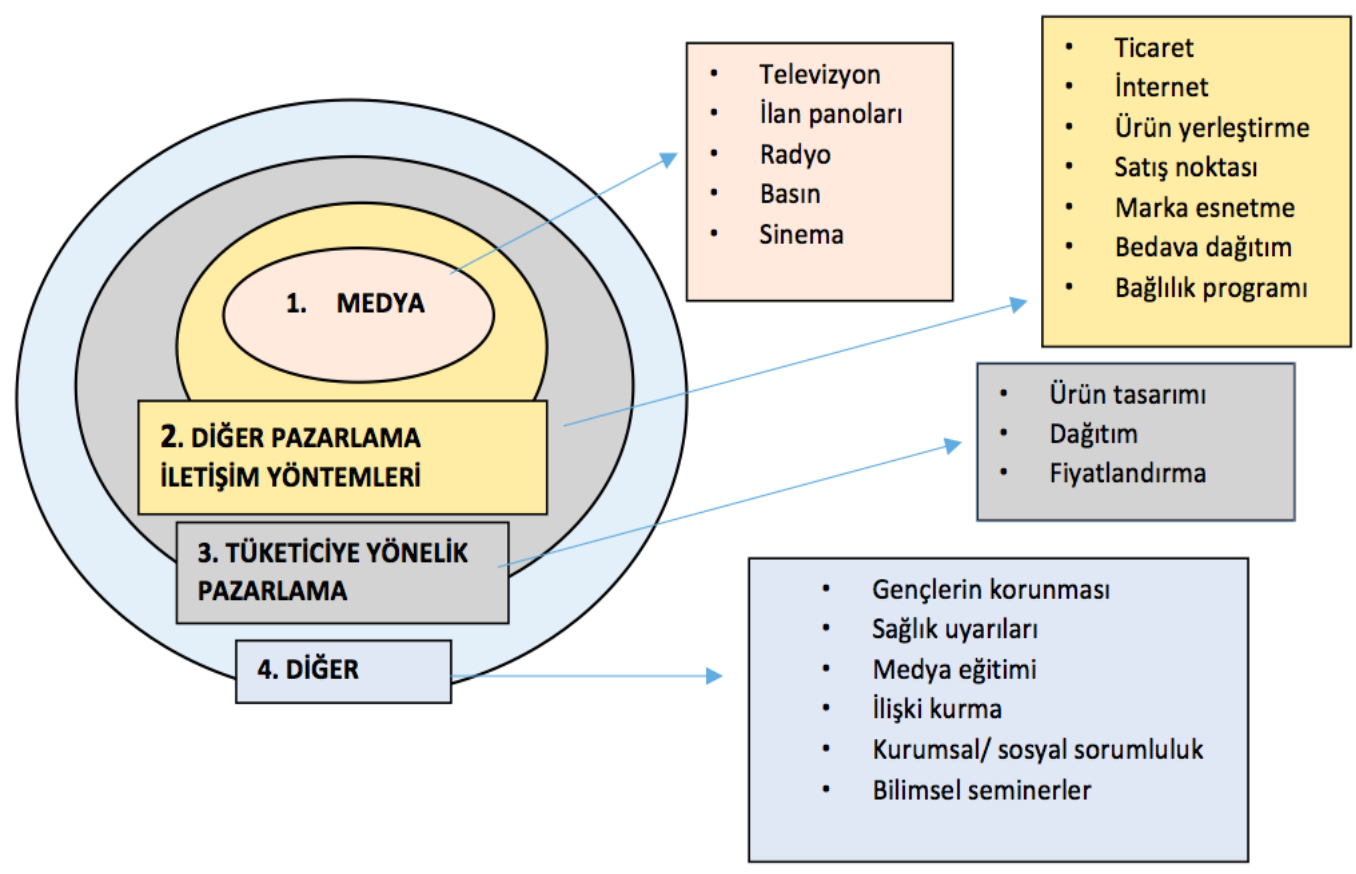

Şekil 1. Tütün tanıtımında reklam, pazarlama iletişimi, tüketici pazarlaması ve ilgili diğer bileşenlerin pazarlama yöntemleri arasındaki iç içe geçmiş ilişkiler

Tütün tanıtımına benzer olarak gıda sektörü de reklam, pazarlama iletişimi, tüketici pazarlaması ve ilgili bileşenlerin pazarlaması arasındaki iç içe geçmiş ilişkilerden yararlanmaktadır. Yukarıda belirtilen başlıklarla ilgili gıda endüstrisinin de kullandığı bazı taktikler aşağıdaki bölümde sunulmuştur.

\subsection{Tüketicileri aldatmak}

Gıdalardaki hilelerin tarihi Orta Çă̆'a kadar dayanmaktadır. Günümüzde, durum çok daha karmaşıktır. Bilimsel ve teknolojik gelişmeler gıda ürünlerindeki hilelerin tespitini kolaylaştırırken aynı bilimsel ve teknolojik gelişmeler daha karmaşık hilelerin de ortaya çıkmasına yardımcı olmaktadır ve teknolojik 
gelişmelerin etkisiyle ürünlerindeki hilelerin tespiti de daha zor bir hal almaktadır. Bilinçsizce kullanılan katkı maddeleri, kontamine gıdaların (pestisitler, ağır metaller, hormonlar ve diğer bulaşanlarla) tüketime sunulması insan sağlığını tehdit eden en önemli gida hilelerindendir. ${ }^{16}$

$\checkmark \quad$ Tüketilen ürünün etiket bilgileri doğru mu?

$\checkmark$ Ürün, etiket bilgisine uygun mu?

$\checkmark$ Organik diye alınan gıda gerçekten organik mi?

$\checkmark \quad$ Katkı maddesi kullanılmış mı?

$\checkmark$ Ürün belirtilenden daha düşük kalitede mi?

$\checkmark$ Sağlık açısından risk taşıyor mu?", soruları hile açısından akla gelmektedir.

Gıda ürünlerinde en çok rastlanan hile çeşidi taklittir. Taklit, "gıda ürünlerinin şekil, bileşim ve nitelikleri itibartyla yapısinda bulunmayan özelliklere sahip gibi veya başka bir ürünün aynısıymış gibi gösterilmesi" olarak bilinir. Tağşiş ise "bir ürünün doğallığının başka bir ürünle bilinçli veya bilinçsiz olarak değiştirilmesi'" anlamına gelmektedir. Gıda sektöründe tağşişin; "insan sağlığı açısından risk taşımayan, daha sağlıklı, raf ömrü daha uzun gıda üretimi ve benzeri amaçlarla yapılan tağşiş" ve "yüksek kalitedeki ürüne daha düşük kalitede ürünler katarak aynı fiyata gıdalar üretmek" şeklinde açıklanan iki nedeni vardır. Tağşiş, ürün kalitesini düşürerek hem haksız rekabete yol açmakta hem de insan sağlığını ciddi anlamda etkilemektedir. Gidada hile olarak adlandırılan asıl problem de bu noktada başlamaktadır. ${ }^{16}$

Türk G1da Kodeksi'nde gidada bulunan kalıntıların miktarlarına dair yasal sınırlar mevcuttur. Belirtilen yasal sınırların aşılması, insan sağlığını ciddi anlamda etkilemektedir. Bilinen önemli g1da hilelerine örnek olarak g1da renklendiricileri, zeytinlerde boya kullanılması, bitkisel yağ karışımları, bal içeriğinde yapay tatlandırıcıların kullanılması, et ürünlerindeki tağşiş, alkollü içkilerde metanol kullanımı gibi çeşitli hileler verilebilir. $^{16}$

\section{2. Özel gruplara yönelmek, yeni pazarlar geliştirmek ve reklam stratejileri kullanmak}

Büyük ölçekli perakendeciler ve ayaküstü tüketilen gıda (fast food) zincirleri gıdanın göreli fiyatını düşürmüş olsalar da reklamcılık ve pazarlama mesajları birleştirildiğinde daha fazla tüketim sağlanmıştır. Bu durum, sağlık sorunlarına ve zararlı çevresel etkilere neden olabilmektedir. ${ }^{17}$

Ortalama genç bir kişi, yılda 40.000'den fazla televizyon reklamı izlemektedir. Gençler internet, dergiler ve video oyunları aracılığıyla tanıtım mesajları almaktadır. $\mathrm{Bu}$ mesajlar çocukların kalorisi yoğun besin maddelerini tercih etmesine, talep etmesine ve tüketmesine neden olabilmektedir. ${ }^{24}$

Amerikalılar, 1945 yılında alkolsüz içeceklerden daha fazla süt içmekteyken 50 yıl sonra sütten yaklaşık iki buçuk kat daha fazla gazlı içecek tüketmişlerdir. ${ }^{17}$

Alkolsüz içecek tüketimindeki artışın sebepleri mısır şurubu imalatçılarına yapmış oldukları reklam ve ağır sübvansiyonlar olup 1985 yılında ilk defa kamış ve şeker pancarını

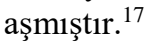

Araştırmalara göre TV reklamına maruz kalma, belki de ABD'deki çocukların şişmanlık salgınından sorumlu olan en büyük faktördür. Özellikle çocuklara gida pazarlama ve reklamcılığının daha fazla düzenlenmesi artık çok daha fazla dikkat çekmektedir. ${ }^{17}$

\subsection{Yasal düzenlemeye yönelik girişimlerin karşısında durmak, yasal düzenlemeleri erteletmek}

Endüstri tarafindan finanse edilen akademik araştırmaların bu alandaki etkisinin, reforma direnen en etkili endüstri taktiklerinden biri olduğu düşünülmektedir. ${ }^{17}$

\subsection{Yasal düzenlemelere zarar veren çalışmalar içinde olmak}

Halk sağlığı politikasındaki gıda endüstrisi etkileri hakkındaki yayınlar artmaktadır ancak g1da endüstrisi belgelerinin analizi nadirdir. 1959-1971 yılları arasinda daha önce belgelenmemiş kurabiye ve şeker pancarı endüstrisi faaliyetlerinin tartışıldığı bir dizi makalenin analizinin yapıldığ 1 bir araştırmada şeker endüstrisi, alımı kısıtlamak yerine şeker tüketiminin zararlarını azaltacak halk sağlığ müdahalelerine (örneğin florid kullanımı) dikkatleri çekmek için bir strateji geliştirmişlerdir. ${ }^{22}$

Endüstri taktikleri arasında; yürütülen gıda endüstrileri ile iş birliği içinde diş plağını parçalamak ve diş çürümesine karşı yaygın bir aşı uygulaması, araştırma olanakları çerçevesinde danışmanlık yapmak, rapor sunmak gibi aktiviteler yer almıştır. ${ }^{22}$ 


\section{5. "Özdenetleme" söylemi üzerinden çeşitli "aldatmacalar" içinde olmak}

Kamuoyunun farkındalığı ve hükümet müdahalesi sonucu, büyük gıda endüstrisi diğer işletmelerin geçmişte yaptığı gibi hareket ederek kendi kendini düzenleme girişimlerini kabul etmeyi taahhüt etmişlerdir. $\mathrm{Bu}$ tür gönüllü eylemler, tehdit altındaki sanayilerin karakteristik özelliklerini taşımakta ve tipik olarak kendi ürettiği kuralları ve standartları takip etme sözlerini içermektedir. ${ }^{25}$

Gıda endüstrisi, tüketimi sağlık endişeleriyle ilişkilendiren ürünler (tütün ve alkol) gibi geniş öz düzenleyici sistemleri geliştirmiştir. ${ }^{25}$ G1da endüstrisinin özdenetiminin yararlı ya da zararlı olacağı henüz bilinmemekte ancak bir endüstrinin hükümet, tüketiciler ya da kamu sağlığı savunucuları girdisi olmaksızın kendi kendini düzenlemesine izin vermenin ciddi sonuçlar doğurabileceği düşünülmektedir. ${ }^{25}$

Bugüne kadar gıda endüstrisinin öz denetimi, dört ana girişimi içermektedir: Biri okuldaki yiyecek ve içecekler, ikisi çocuklara pazarlama, bir diğeri de menü etiketi ile ilgilidir. $^{25}$

\section{Endüstri taktiklerinin sağlık açısından oluşturduğu riskler}

Gıda endüstrisi, ucuz gıdalara hızlı erişim sağlayarak sektörde etkin bir yer kazanmıştır. ${ }^{17}$ Çin'de son 20 yılda endüstri, şişmanlık prevalans hızındaki artışla uyumlu olarak genişlemiştir. ${ }^{25}$ Endüstrinin ürettiği gıdalar kişilerin tuz, yağ ve şeker talebini karşılasa da yüksek kalorili, yüksek tuz ve doymuş yağdan zengin olduğu gerçeği, bu tür işlenmiş yiyecek ve içecek ürünlerinin aşırı alımının bir dizi sağlıkla ilgili soruna neden olduğunu ve sonucunda da şişmanlık salgınının oluştuğunu ortaya koymaktadır. ${ }^{17}$ Örneğin, sağlıksız beslenme sonucu ABD'de günde yaklaşık bin ölüm yalnızca kardiyovasküler hastalıklar ve diyabete bağlı olarak gerçekleşmektedir. Diyetle ilgili kronik hastalıkların doğrudan ve dolaylı maliyetleri ise şaşırtıcıdır ve ABD'de y1lda 1 trilyon dolara kadar çıkmaktadır. ${ }^{8}$ Son 10 yılda her kıta için ciddi gıda kaynaklı hastalıklar ortaya çıkmış ve bu hastalıklar sıklıkla küresel ticaretten etkilenmiştir. ${ }^{25}$

Süpermarketler, özellikle gelişmekte olan ülkelerde; işlenmiş, yüksek yağli, şekerli ve tuz yükü fazla gidaların daha ucuz, daha az sağlıklı yiyeceklerin artan ulaşılabilirliğine yol açabilmektedir. ${ }^{17}$ Ayrıca dışarıda yemek yemenin yaygınlaşması ile beraber tüketilen porsiyon boyutlarında da son y1llarda belirgin bir artış meydana gelmiştir. ${ }^{26}$

Bir dizi halk sağlığı sorunu da dahil olmak üzere sektörde 'şekerle ilgili' önemli alanların kritik incelemelerinin de göz önünde bulundurulması önerilmiştir. $\mathrm{Bu}$ incelemeler sonucu şekerin ''diş çürüğü, şişmanlık ve aterosklerotik vasküler hastalık' kaynağ olduğu görülmüştür. ${ }^{22}$

\section{Halk sağlığı bakış açısı konuya nasıl yaklaşmalıdır?}

Sağlıklı beslenme, dünya çapında temel insan hakk1 olarak kabul görmektedir. Sağlıksız beslenmenin ve beslenmeyle ilişkili bulaşıcı olmayan hastalıkların etkin bir şekilde önlenmesi ve kontrol edilmesi için uygun stratejiler geliştirilmeli ve uygulanmalıdır. ${ }^{6}$

Yetersiz ve dengesiz beslenmenin nedenleri araştırıldığında, bilgi eksikliğinin büyük önem taşıdığı görülmektedir. $\mathrm{Bu}$ nedenle dengesiz beslenmenin önlenmesinde, beslenme eğitimi ve sağlıklı beslenme bilincinin kazandırılması büyük önem taşımaktadır ve bu konuda diyetisyenlere büyük rol düşmektedir. ${ }^{3}$

Artık birçok anayasada güvence altına alınmış olan gıda hakkının elde edilmesi için, kapsamlı g1da ve beslenme güvenliğinin sağlandığı sürdürülebilir, adaletli, erişilebilir, esnek gıda sistemlerine ve bulaşıcı olmayan hastalıkları önlenmek ve sağlık için besin kaynağı olan gıdaların temini ve tüketimine ihtiyaç duyulmaktadır. ${ }^{6}$

Avrupa Gida ve Beslenme Eylem Planı 20152020 'DSÖ, Avrupa bölgesinde hala yaygın olan beslenmeyle ilişkili önlenebilir bulaşıcı olmayan hastalıkların, şişmanliğın ve diğer bütün sağllksız beslenme şekillerinin yükünü önemli oranda azaltmak," amaciyla planlanmıştır. Misyonu ise 'Health (Sağlık) 2020 kapsamında sektörler arası politikalar yoluyla DSÖ Avrupa bölgesinin bütün vatandaşları için beslenmede tarafsızlık ve cinsiyet eşitliği ile birlikte uygun maliyetli, dengeli, sağllklı gıdalara dünya çapında erişim sağlamaktır."' Bu eylem planı, bütüncül devlet ve tüm politikalarda sağlık yaklaşımı ile eylem çağrısında bulunmaktadır. ${ }^{6}$

Sağlık üzerinde olumsuz faaliyetler gösterebilen gıda endüstrisinin iyi araştırılması ve endüstrinin bu etkilerini ortadan kaldıracak önlemlerin alınması son derece önemlidir. Ayrıca toplumun bilinçlendirilmesi ve özellikle gıda sunucularının sorumluluklarının 
arttırılması da önemlidir. Sağlığı olumsuz etkileyen durumları denetlemek amaciyla yeterli sayıda, geniş katılımlı ve uzmanların yer aldığı etik kurullarının bulunması sektör ve toplum için kaçınılmazdır (kurullarda; kamu, sivil toplum, üniversite, özel sektör ve çiftçi temsilcileri yer almalıdırlar). ${ }^{16}$

\section{ÖNERILLER}

G1da endüstrinin sağlı̆̆ olumsuz yönde etkileyecek faaliyetlerinin önlenmesi ve/ veya ortadan kaldırılması birey ve toplum için son derece önemlidir. Bunun sağlanması için yasa yapıcılar ve kamu kuruluşlarının, sağlık profesyonellerinin, gıda endüstrisinin, özel sektörün, sivil toplum kuruluşları (STK) ve medyanın sorumluluğu fazladır. Gıdaya ulaşan bireylerin de gida alımı sirasında dikkat etmesi gereken durumlar bulunmaktadır. Bu konudaki bileşenler kamu ağırlıklı olmak üzere kamusal düzenlemeler zemininde birey/toplum, sivil toplum örgütleri, meslek örgütleri, medya, üniversiteler vb. olarak tanımlanabilir.

Temel bileşenler dikkate alındığında temel bileşenlerin her birisinin ve/veya birkaçının katkısı ile işlevlerin de tanımlanması gerekmektedir. İlgili bütün birey ve kurumların yaklaşımlarının halk sağlığında "ihtiyatlılık ilkesi” gereğince olması beklenmektedir. İhtiyatll1ık ilkesi "herhangi bir ürünün riskleri bilinmediğinde riskli olarak kabul edilmesi ve gerekli bütün önlemlerin alınmasıdır. ${ }^{27}$ Gıda endüstrisinin taktiklerinin zararlı etkilerinin önlenmesi açısından Şekil 1'de de tanımlanmış olan alt bileşenlere düşen rol ve sorumluluklar aşağıda açıklanmıştır:

\section{Kamusal zeminde aşağıdaki faaliyetler sürdürülebilir.}

$\checkmark \quad$ Sağlıklı beslenmenin temel bir sağlık hakkı olduğu bilincinin ve bu bilinçle uyumlu gerekliliklerin yerine getirilmesi ve gereken her türlü düzenlemenin yapılması (örneğin gida güvencesi ve g1da güvenliği kavramlarının gerekliliklerine uygun çalışmalar gibi)

$$
\begin{array}{ll}
\text { - Gerekli kanun } \\
\text { düzenlemelerinin yapılması }
\end{array}
$$

$\checkmark$ Endüstri taktiklerini öngörerek kanıta dayalı önleyici çalışmaların yapılması

$\checkmark \quad$ Sürdürülebilir politikaların geliştirilmesi

$\checkmark$ Diğer sektörlerle iş birliği yapılabilecek doğru zeminin tanımlanması
Konuyla ilgili doktor, diyetisyen, gida mühendisi gibi profesyonel meslek gruplarının istihdamının sağlanması

2. Özel sektör bileşeni olarak gıda endüstrisi açısından öneriler

$\checkmark$ Kanunlara uyarak güvenli gida seçeneklerinin üretilmesi

$\checkmark$ Toplumu yanlış yönlendiren, aldatan uygulamaların önlenmesi

$\checkmark$ Etik çerçevenin içselleştirileceği yaklaşımların, eğitimlerin ve uygulamaların geliştirilmesi

$\checkmark$ Ürünleri tüketen kişilerin her türlü bilgilendirilmesine olanak sağlayan üretim süreçlerinin işletilmesi

$\checkmark$ Ulusötesi şirketlerin oyunlarına "hayır" diyebilecek kurumsal yapiların oluşturulması

\section{Birey/ toplum açısından öneriler}

$\checkmark$ Sağlık, gida ve beslenme okuryazarlığının geliştirilmesi

$\checkmark$ Riskli durumlarda başvuru mekanizması ve yöntemleri ile ilgili seçeneklerin bilinmesinin sağlanması

4. Sağlık profesyonelleri açısından öneriler

$\checkmark$ Sağlık, gida ve beslenme okuryazarlığının geliştirilmesini sağlaması

$\checkmark$ Bilgi birikimini, gereksinim duyulan bileşenlerle paylaşılabilmesi

$\checkmark$ Akademik araştırmalar yaparak doğru bilgilerin üretilmesi

$\checkmark$ Poliklinik hizmeti yapan hekimlerin ve diyetisyenlerin, hastaları sağlıklı gıdaya ulaşım konusunda bilgilendirmesi

\section{STK'lar açısından yapılabilecekler}

\section{Savunuculuk sürdürülmesi \\ faaliyetlerinin}

\section{Medya açısından öneriler}

Gıda pazarlama şekillerinin gıda etiği ilkeleri doğrultusunda olması

$\checkmark \quad$ Toplumun doğru bilgilendirilmesi

$\checkmark$ Çocuklar, gençler gibi özel gruplara yönelik gıda tanıtım faaliyetlerinde bulunulmaması 
Sonuç olarak; bütünsel bir bakış açısıyla bireyin ve toplumun sağlıklı beslenebilmesi için gıda endüstrisi açısından istenmeyen ve bu metin içinde ele alınan bazı uygulamaları önlenebilir. Sağlıklı beslenme konusunda sorumluluğu olan her bileşenin kendi rol ve sorumluluğunu bilinçli bir şekilde sürdürebilmesi değerlidir.

\section{KAYNAKLAR}

1. Köksal O, Attila S, Toplum Beslenmesi, Güler Ç, Akın L, Halk Sağlığı Temel Bilgiler 3, 3. Bask1, Ankara. Hacettepe Üniversitesi Yayınları, 2015.s. 1210-1215.

2. Baysal A, Beslenme, Hatiboğlu yayınları, Ankara, 2002.

3. Türkiye'ye Özgü Besin ve Beslenme Rehberi, Hacettepe Üniversitesi Sağlık Bilimleri Fakültesi Beslenme ve Diyetetik Bölümü, Ankara, 2015.s.11-14.

4. International Conference on Nutrition. Final Report of the Conference. Rome December 1992. http://apps.who.int/iris/bitstream/handle/1 0665/61254/a34812.pdf;jsessionid=BB97 AE3DF56EB4FCBE7945C4CB07A5CF?s equence $=1$

(Erişim: 26.7. 2018).

5. Food inspection. http://www.fao.org/food/food-safetyquality/capacitydevelopment/inspection/en/ (Erişim: 27.7.2018).

6. Avrupa Gida ve Beslenme Eylem Planı 2015-2020, Kopenhag, Danimarka, 15-18 Eylül 2014. http://beslenme.gov.tr/content/files/arastir malar/ds_dok_manlar_n_n_t_rk_eye_ek_2 0577820.pdf

(Erişim: 02.01.2018).

7. CDC Estimates of Foodborne Illness: Findings

https://www.cdc.gov/foodborneburden/attr ibution/attribution-1998-2008.html (Erişim: 02.01.2018).

8. Mozaffarian D (Ed.). Conflict of interest and therole of the food industry in nutrition research, JAMA. 2017;317(17):1755-1756. doi:10.1001/jama.2017.3456.

9. Türkiye Çocukluk Çağı (2. Sınıf Öğrencilerde) Obezite Sürveyans1 Girişimi Araştırması (COSI-TUR) 2016. Sağlık Bakanlığı.

10. New World Encyclopedia. Food industry http://www.newworldencyclopedia.org/ent ry/Food industry (Erişim: 17.01.2018).
11. Global Powers of Consumer Products 2015, Connecting with the connected consumer https://www2.deloitte.com/content/dam/D eloitte/global/Documents/ConsumerBusiness/gx-cb-global-powers-consproducts-2015.pdf (Erişim: 17.01.2018).

12. Türkiye İhracatçılar Meclisi Tarım Raporu 2016.

http://www.tim.org.tr/files/downloads/Rap orlar/Tarim_Raporu 2017.pdf (Erişim: 17.01.2018).

13. Risk Yönetimi ve Kontrolü Genel Müdürlüğü http://risk.gtb.gov.tr/data/52c5369148 7c8eca94a7c66a/GIDA\%20SEKT\%C 3\%96R\%C3\%9C\%20RAPORU\%20\% 2010.06.2016.pdf (Erişim: 18.01.2018).

14. WHO Media Center, Food safety. http://www.who.int/mediacentre/factsheet s/fs399/en/

(Erişim: 04.01.2018).

15. Vural H, Tarım ve gida güvenliğinde etik ilkelerin önemi, U. Ü. Ziraat Fakültesi Dergisi, Cilt 29, Say1 2, 2015.s.193-202.

16. Dunn S. The modern food industy and public health: a Galbraithian perspective. http://www.robinson.cam.ac.uk/postkeyne sian/members/seminarpapers/keynes/Dunn 010211.pdf]

(Erișim: 28.12.2017).

17. Kearney J. Food consumption trends and drivers, Phil. Trans. R. Soc. B 2010.p.2793-2807.

18. Akın L. Ulusal Hastalık Yükü Çalışması (2017), Ulusal Hastalık Yükü Çalışması Sonuçları ve Halk sağlığı Yaklaşımı s.7. http://www.tip.hacettepe.edu.tr/ekler/pdf/u lusal_program.pdf. (Erişim: 18.01.2017).

19. Özvarış Ş B, Ulusal Hastalık Yükü Çalışması (2017), 2013 Ulusal Hastalık Yükü Çalışması Sonuçlarından, Halk Sağlığı Açısından Çözüm Önerileri s.13. http://www.tip.hacettepe.edu.tr/ekler/pdf/u lusal_program.pdf, (Erişim: 18.01.2017).

20. Tutar U, Sümer Z, Yıldırım G, Çelik C. (2012). Sivas'ta üretilen sucukların maya ve küf yönünden periyodik olarak incelenmesi,Selçuk Üniversitesi Selçuk Tarım ve Gıda Bilimleri Dergisi 26 (4): 51-54.

21. Thomas SL, David J, Randle M, Daube M, SeniorK, Gambling advocacy: lessons from tobacco, alcohol and junk food. Aust NZ J Public Health 2016. 40:p.211-7. 
22. Kearns CE, Glantz SA, Schmidt LA. Sugar industry influence on the scientific agenda of the national institute of dental research's 1971 national caries program: a historical analysis of internal documents. PLoS Med 2015. 12(3): e1001798.

23. Aslan D. (2010) 'Reklam Yasakları Tütün Endüstrisi Taktikleri' 'başlıklı kongre sunumu, Elazığ. http://www.ssuk.org.tr/eski_site_verileri/e lazig_kongre_sunumlar/dilek_aslan.pdf (Erişim: 15.01.2018).

24. Sharma LL, Teret SP, Brownell KD. The food industry and self-regulation: standards to promote success and to avoid public health failures, Am J Public Health. 2010 February; 100(2): 240-246.

https://www.ncbi.nlm.nih.gov/pmc/articles /PMC2804645/

(Erișim: 15.01.2018).

25. Xue $H$, Cheng $X$, Zhang Q,Wang $H$, Zhang B, Qu W, Wang Y. Temporal growth and spatial distribution of the fast food industry and its relationship with economic development in China - 2005Preventive Medicine 2017 Sep;102:79-85.

26. Öner C, Özdemir M, Telatar B, Yeşildağ Ş. Yemek servisinde kullanılan tabakların boyutu porsiyon algısını etkiliyor mu? TJFMPC www.tjfmpc.gen.tr 2016;10(4):182-187.

27. Turgut N. İhtiyat İlkesi. http://dergiler.ankara.edu.tr/dergiler/38/29 7/2735.pdf

(Erişim: 20.01.2018). 